\title{
Hawksbill turtles Eretmochelys imbricata in El Salvador: nesting distribution and mortality at the largest remaining nesting aggregation in the eastern Pacific Ocean
}

\author{
Michael J. Liles ${ }^{1, *}$, Mauricio V. Jandres ${ }^{2}$, Wilfredo A. López ${ }^{1}$, Georgina I. Mariona ${ }^{1}$, \\ Carlos R. Hasbún ${ }^{3}$, Jeffrey A. Seminoff ${ }^{4}$ \\ ${ }^{1}$ Fundación Zoológica de El Salvador, San Salvador, El Salvador \\ ${ }^{2}$ Instituto de Ciencias del Mar y Limnología de la Universidad de El Salvador, San Salvador, El Salvador \\ ${ }^{3}$ United States Agency for International Development, San Salvador, El Salvador \\ ${ }^{4}$ National Oceanic and Atmospheric Administration - National Marine Fisheries Service, \\ Southwest Fisheries Science Center, La Jolla, California 92037, USA
}

\begin{abstract}
El Salvador has a series of nesting beaches that together host the highest remaining nesting abundance of hawksbill turtles Eretmochelys imbricata in the eastern Pacific Ocean. However, the distribution of hawksbill turtle nesting and causes of hawksbill mortality along the Salvadoran coast are yet to be described. Here, we report on life history information of this population, including body size of nesting hawksbill turtles and clutch size, and mortality along nesting habitat at the following 3 areas in El Salvador: Los Cóbanos Reef Marine Protected Area (Los Cóbanos), Bahía de Jiquilisco-Xiriualtique Biosphere Reserve (Bahía), and Punta Amapala. In 2008, we recorded 310 nesting events by hawksbill turtles over $51.6 \mathrm{~km}$ of nesting habitat, giving an overall nesting density of 6.0 nests $\mathrm{km}^{-1}$; nearly $62 \%$ of total nesting activity and the highest reproductive output occurred in the Bahía. Morphometric data were collected from 26 nesting turtles that ranged from 74 to $88 \mathrm{~cm}$ curved carapace length (mean $\pm \mathrm{SD} ; 81.6 \pm 3.6 \mathrm{~cm}$ ) and 63 to $76 \mathrm{~cm}$ curved carapace width $(70.1 \pm$ $3.4 \mathrm{~cm}$ ). Between 2004 and 2008, a total of 24 hawksbill turtles died in the mangrove and estuarine habitats of the Bahía (18 attributed to blast fishing) and in 2008, 8 hawksbill turtles died due to bycatch in bottom-set gillnets in Los Cóbanos. Given the severely depleted status of hawksbill turtles in the eastern Pacific, conservation action is urgently needed to mitigate their incidental capture in artisanal fisheries gear at primary nesting and foraging areas in El Salvador.
\end{abstract}

KEY WORDS: Hawksbill turtle $\cdot$ Eastern Pacific $\cdot$ Eretmochelys imbricata $\cdot$ Nesting density $\cdot$ Bycatch Blast fishing $\cdot$ Artisanal fisheries $\cdot$ Mangroves

Resale or republication not permitted without written consent of the publisher

\section{INTRODUCTION}

Hawksbill turtles Eretmochelys imbricata are in a state of crisis in many areas throughout the world (Meylan \& Donnelly 1999, Mortimer \& Donnelly 2008). It is estimated that during the last century, hawksbill turtle numbers declined more than $80 \%$ at many important nesting sites throughout its global range (Mortimer \& Donnelly 2008), justifying classification of the species as Critically Endangered on the International Union for Conservation of Nature (IUCN) Red List of Threatened Species (IUCN 2010). The hawksbill turtle population of the eastern Pacific is in an even more perilous situation than the global status suggests and is imminently threatened with extirpation (Nichols 2003, Seminoff et al. 2003, Mortimer \& Donnelly 2008). Of the myriad threats confronting hawksbill turtles in the eastern Pacific, incidental capture by artisanal and 
industrial fishing, collection of eggs for consumption, and alteration of habitat are considered the most severe (Gaos et al. 2010). Clearly, these threats have contributed to the poor population status of hawksbill turtles in the eastern Pacific; however, with marginal environmental conditions contributing to the development of few coral reefs (Dana 1975, Glynn \& Ault 2000), it is also possible that this region was never a major hotspot for hawksbill turtles. Nevertheless, the absence of major hawksbill turtle rookeries in the eastern Pacific and the dispersed nesting of only small numbers of hawksbill turtles along the Pacific coast of Central America (Cornelius 1982, Witzell 1983, Groombridge \& Luxmoore 1989) have further intensified the impacts of these threats on this remnant population and indicate the extreme importance of reducing threats at the remaining nesting sites.

For decades, the occurrence of hawksbill turtle nesting along the $307 \mathrm{~km}$ coastline of El Salvador was unclear due to inconsistencies in data, much of which was anecdotal and inconclusive. Some experts claimed that existing records of nesting hawksbill turtles were incomplete and could not be confirmed (Hasbún \& Vásquez 1999, Arauz 2000), while others stated that low-density hawksbill nesting occurred 25 yr ago on Salvadoran beaches (Mortimer \& Donnelly 2008). Recently, however, nesting by hawksbill turtles in El Salvador has been confirmed in quantities that are considered to be critical to the continued survival of the eastern Pacific population. In a regional assessment presented by Gaos et al. (2010), between 1 January 2007 and 31 May 2009 a total of 540 hawksbill turtle nests were reported by 6 countries in the eastern Pacific, of which 430 (79.6\%) occurred in El Salvador. However, the distribution of these nesting events and the life history characteristics of mature female hawksbills at Salvadoran beaches have yet to be described.

While relatively high nesting abundance provides El Salvador with a unique opportunity to advance hawksbill turtle recovery in the region, conservation gains have been impeded by local threats challenging hawksbill turtle survival, including egg consumption and fisheries bycatch. To address these threats, a legal framework has been established to provide protection to the hawksbill turtle through the ratification of international agreements, such as the Convention on International Trade in Endangered Species of Wild Fauna and Flora (CITES) (República de El Salvador 1986) and the Convention on Biological Diversity (República de El Salvador 1994), and national laws that recognize and extend protection to the hawksbill turtle as an endangered species (República de El Salvador 2001a), that prohibit the collection and sale of marine turtle products for purposes other than conservation (República de El Salvador 2009), and that mitigate the incidental capture of sea turtles in fisheries (República de El Salvador 2001b, 2007). However, limited enforcement of these measures by authorities in concert with the paucity of existing data on life history characteristics and mortality of hawksbill turtles in El Salvador have hampered the effectiveness of efforts to reduce threats and recover this population of marine turtles.

In the present study, we provide the first-ever detailed report on the nesting distribution and life history of hawksbill turtles in El Salvador. This study also presents the first information available on hawksbill turtle mortality at nesting sites with an examination of associated threats. We hope that these data will serve as a basis for developing and promoting effective hawksbill turtle conservation efforts in El Salvador as well as in the entire eastern Pacific region.

\section{MATERIALS AND METHODS}

Study sites. The study was conducted at the following 3 areas in El Salvador where anecdotal reports from local sea turtle egg collectors indicated the occurrence of hawksbill turtle nesting activity (Vásquez et al. 2008): Los Cóbanos Reef Marine Protected Area (Los Cóbanos), Bahía de Jiquilisco-Xiriualtique Biosphere Reserve (Bahía), and Punta Amapala (Fig. 1). Below is a brief description of each.

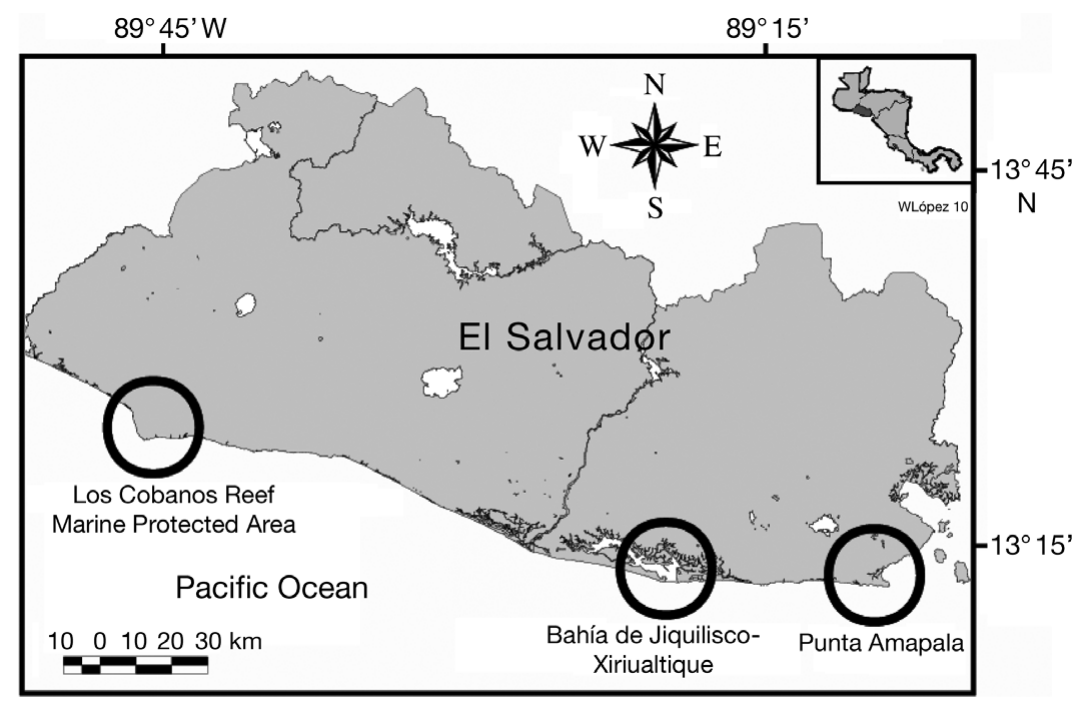

Fig. 1. Study sites. The 3 monitoring areas along the coast of El Salvador are circled 
Los Cóbanos Reef Marine Protected Area: Los Cóbanos $\left(13^{\circ} 31^{\prime} \mathrm{N}, 89^{\circ} 48^{\prime} \mathrm{W}\right)$ is situated $11 \mathrm{~km}$ to the east of Acajutla, and contains $260 \mathrm{~km}^{2}$ of marine and terrestrial areas, with dominant features being a rocky coastline and submerged volcanic reef formations ranging from 0 to $30 \mathrm{~m}$ in depth. Los Cóbanos is home to approximately 15 species of corals and boasts the highest diversity of marine algae, invertebrates, and fish in the country (Orellana 1985, SEMA 1994). A total of 14 coarse-grained beaches composed primarily of crushed shells and coral extend nearly $8 \mathrm{~km}$ from Las Flores to Miravalle, most of which are small coves between rock outcrops with minimal development and intact littoral vegetation present from Las Flores to El Zope and along Miravalle. Las Flores and Chantene are not included within the limits of the protected area.

Bahía de Jiquilisco-Xiriualtique: Located along the south-central coast of El Salvador, the Bahía (13 $13^{\circ} \mathrm{N}$, $88^{\circ} 32^{\prime} \mathrm{W}$ ) was designated a Ramsar wetland in 2005 and named a UNESCO Biosphere Reserve in 2007. With an area of $63500 \mathrm{ha}$, it is the largest expanse of brackish water and saltwater forest in El Salvador and includes numerous estuaries and canals, various isles of different sizes, a freshwater lagoon complex, and seasonally saturated forests connected to the mangroves (www.ramsar.org). The $37 \mathrm{~km}$ extension of hawksbill turtle nesting habitat within the Bahia includes 5 vegetation-fringed, fine-grained sand beaches, of which 4 are insular. Most beaches are shallow-sloped and narrow, with the exception of Isla Madresal and Isla San Sebastian, respectively. Moderate development has occurred in some nesting areas, particularly along western Punta San Juan, eastern Isla Madresal, and northern Isla San Sebastian.

Punta Amapala: The portion of the Gulf of Fonseca within El Salvador is located between $13^{\circ} 9^{\prime}$ to $13^{\circ} 20^{\prime} \mathrm{N}$, and $87^{\circ} 45^{\prime}$ to $88^{\circ} 00^{\prime} \mathrm{W}$. In its entirety, the gulf covers $1800 \mathrm{~km}^{2}$ and is bounded to the northwest by El Salvador, to the northeast by Honduras, and to the southeast by Nicaragua. Its entrance, marked by Punta Amapala in El Salvador and Punta Cosigüina in Nicaragua, is about $32 \mathrm{~km}$ across and widens to $80 \mathrm{~km}$. The shoreline of Punta Amapala consists of 6 beaches that comprise $6.5 \mathrm{~km}$ from Las Tunas to El Faro. Rock outcrops are common at all beaches, with Las Tunas to El Maculís characterized by fine-grained sand and heavy development, and La Pulgosa to El Faro by finegrained sand mixed with stones, intact littoral vegetation, and extensive solid waste contamination. A rocky reef system with coral growth extends the entire length of Punta Amapala and reaches a depth of at least $20 \mathrm{~m}$.

Data collection. Because of the extremely dispersed nature of hawksbill turtle nesting along the Salvadoran coast, maximizing opportunities to measure hawksbill turtles necessitated the involvement of 3 field technicians and a broad group of approximately 60 local sea turtle egg collectors and fishermen, hereafter called local assistants. Field technicians were paid a monthly salary, and local assistants were given a monetary incentive for their collaboration, which included payment for assistance with morphometric data collection and the purchase of hawksbill turtle clutches for incubation in local hatcheries to avoid their sale for consumption. At each site, the field technician and local assistants were trained in hawksbill turtle biology and methods for collecting morphometric data.

Information provided by coastal residents indicated that the hawksbill turtle nesting season runs from midApril through mid-October, with a peak in June and July (Vásquez et al. 2008). From 1 May 2008 through 31 October 2008, each field technician was responsible for patrolling beaches within their area nightly from 17:00 to $05: 00 \mathrm{~h}$ to quantify nesting activity and measure hawksbill turtles. Local assistants were given the cell phone number of the field technician at their site and were instructed to call once a nesting hawksbill turtle or tracks of a successful nesting event had been located. Upon receiving a call from a local assistant, the field technician immediately traveled to the reported location to collect morphometric data or verify tracks; dispersed nesting and limited funds prevented the confirmation of failed nesting attempts (false crawls). When a nesting turtle was present, a flexible tape was used to measure curved carapace length (CCL) from the nuchal notch to the posteriormost tip of the supracaudals and curved carapace width (CCW) of each turtle to the nearest $\mathrm{cm}$. However, due to security concerns at Los Cóbanos, morphometric data were not collected. Clutch size and hatching success were recorded for clutches relocated to local hatcheries. Nest contents were excavated by hand 36 to $96 \mathrm{~h}$ following hatchling emergence, and counts of hatched eggs, unhatched eggs, and hatchlings were made. Clutch size was defined as the total number of eggs (hatched and unhatched) clutch $^{-1}$ and hatching success as the percentage of eggs which produced hatchlings that emerged from the nest. Hatchling releases occurred immediately after emergence from nests, when possible, in controlled environments to avoid losses to predators and disorientation by artificial lights. Throughout the duration of the project, field technicians and local assistants patrolled $60.5 \mathrm{~km}$, of which $51.6 \mathrm{~km}$ were sandy sections comprising 25 hawksbill turtle nesting beaches (Fig. 2).

Mortality was estimated from 2004 to 2008 by reviewing mortality reports of local management authorities, Comité de Desarrollo Empresarial y Medioambiental de Puerto Parada (CODEPA) and Fundación para la Protección del Arrecife de Los Cóbanos (FUNDAR- 


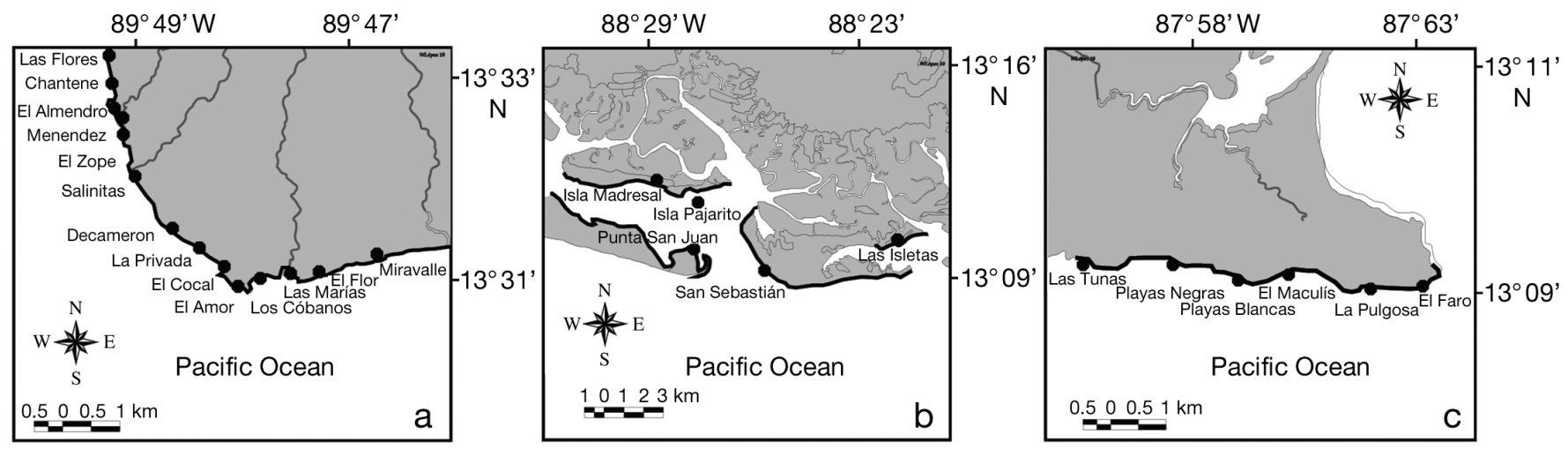

Fig. 2. Monitoring areas in the 3 study sites (a: Los Cóbanos; b: Bahía; c: Punta Amapala), with patrolled shoreline marked with black lines. See Table 1 for lengths of sandy sections

RECIFE), which contained photographs of carcasses and textual descriptions of each hawksbill turtle mortality event. Follow-up interviews were conducted with CODEPA and FUNDARRECIFE staff, as well as local assistants, to supplement mortality information. Lack of local management authorities in Punta Amapala impeded the collection of hawksbill turtle mortality data. We determined the cause of death when possible and categorized mortality as follows: (1) blast fishing: carcasses with fractured carapace and/or ruptured internal organs (Naughton 1985); (2) bottom-set gillnets: carcasses entangled in gillnets or with evidence of gillnet interactions, such as marks on extremities; (3) unknown: carcasses that exhibited no observable cause of mortality.

\section{RESULTS}

In Table 1 we present data on hawksbill turtle nesting density and reproductive output per beach in El Salvador in 2008. A total of 310 hawksbill turtle nesting events resulting in egg deposition were recorded along the Salvadoran coast, with the Bahía by far the most turtle-frequented area, containing $61.9 \%$ of all nests. The mean nesting density over the total available nesting habitat of $51.6 \mathrm{~km}$ was 6.0 nests $\mathrm{km}^{-1}$, which varied greatly among individual beaches; highest nest concentrations were found in Los Cóbanos (mean = 10.1 nests $\mathrm{km}^{-1}$, range $=0$ to 48.6 ) and lowest concentrations in the Bahía (mean $=5.2$ nests $\mathrm{km}^{-1}$, range $=1.3$ to 25.0 ). Of the 310 nesting events, 106 nests (34\% of total) yielding 15125 eggs were encountered and relocated by field technicians or local assistants to hatcheries. Remaining nests were encountered and reported, but extracted for consumption by local egg collectors not participating in the project; therefore, the clutch sizes of these nests were not quantified. The mean clutch size of all relocated nests was $142.7 \pm 30.0$ eggs (range $=72$ to 207), with nests from the Bahía representing the greatest mean clutch size of the 3 areas at $156.7 \pm 23.0$ eggs (range $=117$ to 200 ). It should be noted, however, that recorded clutch sizes are considered a minimum range, as likely only partial clutches were sold to hatcheries during periods when market prices for egg consumption exceeded those offered by hatcheries for conservation, which was confirmed by local assistants for 2 clutches: 72 eggs (El Flor) and 96 eggs (El Cocal). Over the entire nesting habitat, a hatching success of $66.4 \%$ that produced 10039 viable hatchlings was recorded for relocated clutches, with Punta Amapala and the Bahia representing the greatest mean hatching success $(76.8 \%$, range $=62.4$ to $91.0 \%$ ) and the greatest number of viable hatchlings $(4195$, range $=478$ to 1647 ), respectively.

Morphometric data of 26 nesting hawksbill turtles were collected in the Bahía and Punta Amapala. In Los Cóbanos, the presence of gangs evoked security concerns that prevented night patrols by field technicians and inhibited the collection of morphometric data. The 26 mature female turtles ranged from 74 to $88 \mathrm{~cm} \mathrm{CCL}$ $($ mean $\pm \mathrm{SD} ; 81.6 \pm 3.6 \mathrm{~cm})$ and 63 to $76 \mathrm{~cm} \mathrm{CCW}(70.1 \pm$ $3.4 \mathrm{~cm}$ ); the mean size of the 16 nesting turtles in Punta Amapala (83.4 cm CCL) was $4.6 \mathrm{~cm}$ larger than the mean size of the 10 nesting turtles in Bahía $(78.8 \mathrm{~cm}$ CCL), but this is likely an artifact of a small sample size. As no tagging program currently exists in El Salvador, it is possible that morphometric data of the same hawksbill turtle was collected more than once. No data are available on clutch frequency of hawksbill turtles in the eastern Pacific; however, by using the upper range of clutch frequency values of hawksbill turtles in the Caribbean of 4 to 6 clutches (mean $=4.5$, mode $=5$; Richardson et al. 1999), the 310 nesting events likely represent between 52 and 78 individual hawksbill turtles. It is possible that some individuals were encountered on fewer occasions than the mean clutch frequency, thus this should be considered a minimum 
Table 1. Eretmochelys imbricata. Distribution of hawksbill turtle nesting density and reproductive output per beach in El Salvador in 2008. Reproductive output data represent relocated clutches only. BL: beach length (km); LN: number of nests laid; ND: nesting density (nests $\mathrm{km}^{-1}$ ); RC: number of relocated clutches; E: total number of eggs; HS: hatching success of eggs (\%); EH: total number of emerged hatchlings. Los Cóbanos: Los Cóbanos Reef Marine Protected Area; Bahía: Bahía de Jiquilisco-Xiriualtique

\begin{tabular}{|c|c|c|c|c|c|c|c|c|c|c|}
\hline \multirow[t]{2}{*}{ Nesting beach } & \multirow[t]{2}{*}{$\mathrm{BL}$} & \multirow[t]{2}{*}{ LN } & \multirow[t]{2}{*}{ ND } & \multirow[t]{2}{*}{$\mathrm{RC}$} & \multicolumn{3}{|c|}{ Eggs per clutch } & \multirow[t]{2}{*}{$\mathrm{E}$} & \multirow[t]{2}{*}{ HS } & \multirow[t]{2}{*}{$\mathrm{EH}$} \\
\hline & & & & & Range & Mean & $\mathrm{SD}$ & & & \\
\hline \multicolumn{11}{|l|}{ Los Cóbanos } \\
\hline Las Flores & 0.35 & 17 & 48.6 & 12 & $81-144$ & 124.9 & 19.8 & 1499 & 55.4 & 830 \\
\hline Chantene & 0.43 & 18 & 41.9 & 11 & $102-199$ & 147.4 & 37.0 & 1621 & 51.9 & 841 \\
\hline El Almendro & 0.34 & 10 & 29.4 & 8 & $90-156$ & 129.8 & 20.3 & 1038 & 68.9 & 715 \\
\hline Menéndez & 0.20 & 9 & 45.0 & 4 & $108-144$ & 129.0 & 15.1 & 516 & 46.5 & 240 \\
\hline El Zope & 0.45 & 5 & 11.1 & 3 & $90-144$ & 118.0 & 27.1 & 354 & 65.3 & 231 \\
\hline Salinitas & 0.86 & 0 & - & - & - & - & - & - & - & - \\
\hline Decameron & 0.78 & 3 & 3.9 & 0 & - & - & _- & - & - & - \\
\hline La Privada & 0.51 & 0 & - & - & - & - & - & - & - & - \\
\hline El Cocal & 0.15 & 6 & 40.0 & 5 & $92-108$ & 101.2 & 7.2 & 506 & 43.1 & 218 \\
\hline El Amor & 0.28 & 1 & 3.6 & 0 & - & - & - & - & - & - \\
\hline Los Cóbanos & 0.57 & 0 & - & - & - & - & - & - & - & - \\
\hline Las Marías & 0.39 & 3 & 7.7 & 3 & $123-192$ & 153.0 & 35.4 & 459 & 75.6 & 347 \\
\hline El Flor & 0.99 & 4 & 4.0 & 1 & 72 & 72.0 & - & 72 & 79.2 & 57 \\
\hline Miravalle & 1.49 & 3 & 2.0 & 3 & $128-204$ & 159.3 & 39.7 & 478 & 72.8 & 348 \\
\hline Overall & 7.79 & 79 & 10.1 & 50 & $72-204$ & 130.9 & 30.2 & 6543 & 58.5 & 3827 \\
\hline \multicolumn{11}{|l|}{ Bahía } \\
\hline Las Isletas & 1.80 & 45 & 25.0 & 13 & $119-192$ & 160.0 & 25.6 & 2080 & 79.2 & 1647 \\
\hline Isla Madresal & 9.04 & 36 & 4.0 & 14 & $134-200$ & 157.9 & 17.7 & 2210 & 50.6 & 1118 \\
\hline Isla Pajarito & 0.75 & 9 & 12.0 & 7 & $117-180$ & 146.6 & 25.9 & 1026 & 92.8 & 952 \\
\hline San Sebastián & 12.87 & 17 & 1.3 & 4 & $128-189$ & 160.0 & 29.2 & 640 & 74.7 & 478 \\
\hline Punta San Juan & 12.86 & 85 & 6.6 & 0 & - & - & - & - & - & - \\
\hline Overall & 37.32 & 192 & 5.2 & 38 & $117-200$ & 156.7 & 23.0 & 5956 & 70.4 & 4195 \\
\hline \multicolumn{11}{|l|}{ Punta Amapala } \\
\hline Las Tunas & 1.08 & 1 & 0.9 & 0 & - & - & - & - & - & - \\
\hline Playas Negras & 1.05 & 2 & 1.9 & 0 & - & - & - & - & - & - \\
\hline Playas Blancas & 0.58 & 3 & 5.2 & 2 & $143-169$ & 156.0 & 18.4 & 312 & 87.8 & 274 \\
\hline El Maculís & 1.58 & 8 & 5.1 & 5 & $121-181$ & 145.2 & 32.2 & 726 & 62.4 & 453 \\
\hline La Pulgosa & 1.25 & 11 & 8.8 & 4 & $118-207$ & 164.0 & 48.1 & 656 & 91.0 & 597 \\
\hline El Faro & 0.94 & 14 & 14.9 & 7 & $120-168$ & 133.1 & 17.8 & 932 & 74.4 & 693 \\
\hline Overall & 6.48 & 39 & 6.0 & 18 & $118-207$ & 145.9 & 30.7 & 2626 & 76.8 & 2017 \\
\hline
\end{tabular}

estimate. Future tagging efforts will provide additional insights about nesting history of individual turtles.

From 2004 to 2008, a total of 32 dead hawksbill turtles were recorded in the Bahía and Los Cóbanos (Table 2), of which 24 (75\%) were turtles of larger size classes (CCL > $70 \mathrm{~cm}$ ). In the Bahía, fishing with explosives, or blast fishing, was responsible for 18 (75\%) of the 24 hawksbill turtle deaths, with the source of mortality of the remaining 6 turtles unknown. In 2008, interactions with bottom-set gillnets in Los Cóbanos resulted in the deaths of 8 sub-adult hawksbill turtles.

\section{DISCUSSION}

El Salvador is considered the site of greatest remaining nesting abundance of hawksbill turtles in the eastern Pacific Ocean (Gaos et al. 2010). With nearly $62 \%$ of total nesting activity and the highest reproductive out- put recorded along the Salvadoran coast, the $37 \mathrm{~km}$ extension of dispersed beaches in the Bahía is clearly the most important nesting habitat for hawksbill turtles in

Table 2. Eretmochelys imbricata. Recorded hawksbill turtle mortality and its causes in El Salvador from 2004 to 2008. CCL: curved carapace length. Bahía: Bahía de Jiquilisco-Xiriualtique;

Los Cóbanos: Los Cóbanos Reef Marine Protected Area

\begin{tabular}{|lccl|}
\hline Year & $\mathrm{n}$ & CCL $(\mathrm{cm})$ & Cause \\
\hline Bahía & & & \\
2004 & 2 & $>70$ & Unknown \\
2005 & 2 & $>70$ & Unknown \\
2006 & 4 & $>70$ & Blast fishing \\
2007 & 8 & $>70$ & Blast fishing (6), \\
2008 & 8 & $>70$ & Bnknown (2) \\
Los Cóbanos & & & \\
2008 & 8 & $35-50$ & Bottom-set gillnets \\
\hline
\end{tabular}


the country. Substantial nesting also occurred from Las Flores to Menéndez ( $\mathrm{n}=54$ nests, mean nesting density $=41.9$ nests $\mathrm{km}^{-1}$ ) and from La Pulgosa to El Faro ( $\mathrm{n}=$ 25 nests, mean nesting density $=11.4$ nests $\mathrm{km}^{-1}$ ), which represented $68 \%$ and $64 \%$ of all nesting activity in Los Cóbanos and Punta Amapala, respectively.

In low-income nations such as El Salvador, the extraction and direct use of natural resources remains an essential livelihood strategy for many people (Hutton \& Leader-Williams 2003), particularly in rural and coastal areas where poverty is most acute (Lehoucq et al. 2004). Concurrently, with a total area of $21040 \mathrm{~km}^{2}$ and an estimated population density of 342 people $\mathrm{km}^{-2}$, El Salvador is the smallest and most denselypopulated country in Central America. For these reasons, in concert with virtually unregulated resource use, the protection of marine turtle nests in situ has been considered infeasible. Since at least 1975, hatcheries have been the primary method used to protect sea turtle nests along the Salvadoran coast (C. R. Hasbún pers. obs.). By purchasing eggs from local egg collectors, hatcheries provide an alternate economic incentive to sale for consumption and thus have gained acceptance among coastal communities; eggs not purchased by hatcheries are sold for consumption (Hasbún \& Vásquez 1999, Vásquez et al. 2008). Therefore, we believe that the relocation of hawksbill clutches to hatcheries is the only feasible option to ensure their protection. However, reduced hatching success may have resulted due to the physical handling of eggs (Limpus et al. 1979) and to the differences between the original and relocated nest environments (Miller 1997). While the loss of 204 hawksbill turtle nests (66\% of total) to consumption is of concern, the Salvadoran government recently prohibited the collection and sale of marine turtle products for purposes other than conservation (República de El Salvador 2009), which has further elevated the role of hatcheries in egg protection as a means of encouraging legislative compliance and underscores the need to examine how methods used to relocate clutches may affect hatching success.

In contrast to the priority status awarded to nest conservation, hawksbill turtle bycatch in artisanal fisheries, particularly blast fishing and bottom-set gillnets, has received little attention from the Salvadoran government and is among the most serious threats immediately challenging hawksbill turtle survival at primary nesting sites in El Salvador.

\section{Blast fishing}

Blast fishing is an unselective, destructive practice that can have widespread implications for marine habitats and biodiversity. Attention has been given to the impacts of blast fishing on tropical coral reef ecosystems (e.g. Alcala \& Gomez 1987, Jennings \& Polunin 1996, Gray 1997, Wells 2009) and to a lesser extent on mangrove ecosystems (e.g. Corcoran et al. 2007, Adekanmbi \& Ogundipe 2009), but few data are available regarding the impacts of blast fishing on marine turtles inhabiting these ecosystems. Our study underscores blast fishing as a major threat to hawksbill turtles in mangrove ecosystems.

Despite its prohibition in territorial waters and classification as a grave violation by Salvadoran law (República de El Salvador 2001b), the use of explosives as a fishing method by groups of fishers in the Bahía is common. Approximately 90 blast fishers circulate within the Bahía using homemade bottle bombs composed of sulfur, chlorate, and sugar to target commercially valuable fish species for sale in local markets, with each boat containing a 3 person crew and occupying a selected fishing area for 12 to $15 \mathrm{~d}$ (M. V. Jandres pers. obs.). The indiscriminate nature of blast fishing kills all class sizes of target and non-target species, with most fish sinking to the bottom and many not collected, especially if fishers are only free-diving (Fox \& Erdmann 2000).

Recent satellite telemetry data illustrate that the same mangrove and estuarine habitats serving as critical nesting grounds for hawksbill turtles in the Bahía are also important foraging areas for adult individuals (A. Gaos pers. comm.). Blast fishers targeting fish aggregations throughout the Bahía are having fatal interactions with hawksbill turtles that utilize the same habitat. As high survival rates of individuals from older age classes are needed for long-term population growth and recovery, particularly for populations at already reduced levels (Heppell \& Crowder 1998, Heppell 1998, Heppell et al. 2003, Campbell \& Lagueux 2005), the loss of at least 18 hawksbill turtles of larger size classes to blast fishing during a 3 yr period from a remnant population whose status 'is clearly of a highest concern for the Pacific' (NMFS \& USFWS 1998, p. vi) is of grave concern and should be urgently addressed. With no action currently being taken by the Salvadoran government to eliminate this illegal practice, it is likely that hawksbill turtle mortality by blast fishing will continue until its remedy is made a priority or until hawksbill turtles are extirpated in the Bahía.

\section{Bottom-set gillnets}

There is growing evidence that small-scale, passive net fisheries are a significant mortality source for some marine turtle populations (Gilman et al. 2009), particularly in low-income nations where management and enforcement are limited (Hamann et al. 
2006, Peckham et al. 2007). In Los Cóbanos, over 700 artisanal fishers operate from approximately 340 boats and 30 canoes, with bottom-set gillnets as a commonly utilized fishing method (ICMARES 2006). Gillnets (300 m long by 1 to $1.5 \mathrm{~m}$ deep; mesh size, $10 \mathrm{~cm}$; line-test, 4 lbs) targeting Pacific green spiny lobsters Panulirus gracilis are set at at least 30 primary fishing sites once daily with a $12 \mathrm{~h}$ soak time at depths of between 3 and $7 \mathrm{~m}$ (W. A. López pers. obs.). The reliance of hawksbill turtles on coral reef ecosystems as primary foraging grounds is well documented (e.g. Meylan 1988, León \& Bjorndal 2002, Spotila 2004). As such, interactions between hawksbill turtles and bottom-set gillnets are occurring when located within their foraging areas, as evidenced by the deaths of 8 sub-adult hawksbill turtles in 2008. Population modeling has demonstrated that high survivorship of subadults, in addition to mature female turtles, is important in maintaining viable marine turtle populations (Crouse et al. 1987, Crouse 1999), making this scenario particularly alarming.

\section{CONCLUSIONS}

Anthropogenic pressures on existing resources and habitats in Central America are expected to increase as human populations continue to rise, further threatening biodiversity (Harvey et al. 2008) and the survival of the hawksbill turtle of the eastern Pacific Ocean. As the site of the largest remaining nesting aggregation in the region, conservation efforts directed at hawksbill turtles in El Salvador have been identified as a top priority (Gaos et al. 2010). The occurrence of relatively high numbers of nesting and foraging hawksbill turtles in Los Cóbanos Reef Marine Protected Area, Bahía de Jiquilisco-Xiriualtique Biosphere Reserve, and Punta Amapala offers a unique opportunity to facilitate the slow process of their recovery in the eastern Pacific. However, such advances have yet to be realized as blast fishing and bottom-set gillnet induced mortality are instead driving hawksbill turtles toward extirpation in El Salvador. Conservation action by the Salvadoran government is urgently needed to mitigate the incidental capture of sub-adult and adult hawksbill turtles in artisanal fisheries, as their survival is critical in preventing further declines of this highly threatened population. Further efforts in studying the human dimensions of hawksbill turtle conservation, as well as molecular genetic studies to define regional management units (Wallace et al. 2010), could provide information to inform the prioritization of hawksbill turtle nesting beach conservation at multiple scales throughout the eastern Pacific Ocean.
Acknowledgements. We thank the US National Fish and Wildlife Foundation (NFWF) for financial assistance and the Ministerio de Medio Ambiente y Recursos Naturales (MARN) for permits. We gratefully acknowledge the local organizations that were integral to the success of this work, particularly FUNDARRECIFE, CODEPA, and the Fishing Cooperative of El Maculís, and our special gratitude goes to the network of local assistants along the coast of El Salvador who assisted with data collection. We are indebted to our many colleagues for constructive reviews of this manuscript and continued support, including A. Gaos, W. J. Nichols, T. R. Peterson, and B. Wallace. We also thank M. Hamann and 4 anonymous reviewers for excellent comments on earlier drafts.

\section{LITERATURE CITED}

Adekanmbi H, Ogundipe O (2009) Mangrove biodiversity in the restoration and sustainability of the Nigerian natural environment. J Ecol Nat Environ 1:64-72

Alcala AC, Gomez ED (1987) Dynamiting coral reef for fish: a resource-destructive fishing method. In: Salvat B (ed) Human impacts on coral reefs: facts and recommendations. Antenne Museum EPHE, Papeete, p 51-60

Arauz R (2000) Diagnostico de la situación actual de las tortugas marinas en El Salvador. MARN, San Salvador

> Campbell CL, Lagueux CJ (2005) Survival probability estimates for large juvenile and adult green turtles (Chelonia mydas) exposed to an artisanal marine turtle fishery in the western Caribbean. Herpetologica 61:91-103

Corcoran E, Ravilious C, Skuja M (2007) Mangroves of western and central Africa. UNEP World Conservation Monitoring Centre, Cambridge

Cornelius SE (1982) Status of sea turtles along the Pacific coast of Middle America. In: Bjorndal KA (ed) Biology and conservation of sea turtles. Smithsonian Institution Press, Washington, DC, p 211-219

Crouse DT (1999) The consequences of delayed maturity in a human-dominated world. Life in the slow lane: ecology and conservation of long-lived marine animals. Am Fish Soc Symp 23:195-202

Crouse DT, Crowder LB, Caswell H (1987) A stage-based population model for loggerhead sea turtles and implications for conservation. Ecology 68:1412-1423

> Dana TF (1975) Development of contemporary eastern Pacific coral reefs. Mar Biol 33:355-374

Fox HE, Erdmann MV (2000) Fish yields from blast fishing in Indonesia. Coral Reefs 19:114

Gaos AR, Abreu-Grobois A, Alfaro-Shigueto J, Amorocho D and others (2010) Signs of hope in the eastern Pacific: international collaboration reveals encouraging status for a severely depleted population of hawksbill turtles Eretmochelys imbricata. Oryx 44:595-601

Gilman E, Gearhart J, Price B, Eckert S and others (2009) Mitigating sea turtle by-catch in coastal passive net fisheries. Fish Fish 11:57-88

> Glynn PW, Ault JS (2000) A biogeographic analysis and review of the far eastern Pacific coral reef region. Coral Reefs 19:1-23

Gray JS (1997) Marine biodiversity: patterns, threats and conservation needs. Biodivers Conserv 6:153-175

Groombridge B, Luxmoore R (1989) The green turtle and hawksbill (Reptilia: Cheloniidae): world status, exploitation and trade. CITES Secretariat, Lausanne

> Hamann M, Cuong CT, Hong ND, Thuoc P, Thuhien BT (2006) Distribution and abundance of marine turtles in the Socialist Republic of Viet Nam. Biodivers Conserv 15: 3703-3720 
Harvey CA, Komar O, Chazdon R, Ferguson BG and others (2008) Integrating agricultural landscapes with biodiversity conservation in the Mesoamerican hotspot. Conserv Biol 22:8-15

Hasbún CR, Vásquez M (1999) Sea turtles of El Salvador. Mar Turtle Newsl 85:7-9

Heppell SS (1998) Application of life-history theory and population model analysis to turtle conservation. Copeia 1998: 367-375

Heppell SS, Crowder LB (1998) Prognostic evaluation of enhancement programs using population models and life history analysis. Bull Mar Sci 62:495-507

Heppell SS, Snover ML, Crowder LB (2003) Sea turtle population ecology. In: Lutz PL, Musick JA, Wyneken J (eds) The biology of sea turtles, Vol 2. CRC Press, Boca Raton, FL, p 275-306

Hutton JM, Leader-Williams N (2003) Sustainable use and incentive-driven conservation: realigning human and conservation interests. Oryx 37:215-226

ICMARES (Instituto de Ciencias del Mar y Limnología de El Salvador) (2006) Diagnostico de la línea base de las condiciones biofísicas, socioeconómicas e institucionales del Sistema Arrecifal de Los Cóbanos. Universidad de El Salvador, San Salvador

IUCN (International Union for Conservation of Nature) (2010) The IUCN red list of threatened species, Version 2010.1. Available at www.iucnredlist.org

Jennings S, Polunin NVC (1996) Impacts of fishing on tropical reef ecosystems. Ambio 25:44-49

Lehoucq F, Goodin J, O'Donnell M, Molina JF (2004) Conflict assessment: El Salvador. USAID, San Salvador

León YM, Bjorndal KA (2002) Selective feeding in the hawksbill turtle, an important predator in coral reef ecosystems. Mar Ecol Prog Ser 245:249-258

Limpus CJ, Baker V, Miller JD (1979) Movement induced mortality of loggerhead eggs. Herpetologica 35:335-338

Meylan A (1988) Spongivory of hawksbill turtles: a diet of glass. Science 239:393-395

Meylan AB, Donnelly M (1999) Status justification for listing the hawksbill turtle (Eretmochelys imbricata) as Critically Endangered on the 1996 IUCN Red List of Threatened Animals. Chelonian Conserv Biol 3:200-224

Miller JD (1997) Reproduction in sea turtles. In: Lutz PL, Musick JA (eds) The biology of sea turtles. CRC Press, Boca Raton, FL, p 51-81

Mortimer JA, Donnelly M (2008) Eretmochelys imbricata. In: IUCN Red List of Threatened Species, Version 2010.1. Available at www.iucnredlist.org

Naughton J (1985) Blast fishing in the Pacific. SPC Fish Newsl $33: 16-20$

Nichols WJ (2003) Biology and conservation of sea turtles in Baja California, Mexico. PhD thesis, School of Renewable Resources, University of Arizona, Tucson, AZ

NMFS (National Marine Fisheries Service), USFWS (US Fish and Wildlife Service) (1998) Recovery plan for U.S. Pacific populations of the hawksbill turtle (Eretmochelys imbricata). National Marine Fisheries Service, Silver Spring, MD

Editorial responsibility: Mark Hamann,

Townsville, Australia
Orellana AJJ (1985) Peces marinos de Los Cóbanos, El Salvador. Fundación SIGMA, San Salvador

Peckham SH, Maldonado D, Walli A, Ruiz G, Nichols WJ, Crowder L (2007) Small-scale fisheries bycatch jeopardizes endangered Pacific loggerhead turtles. PLoS ONE 2:e1041

República de El Salvador (1986) Convención internacional sobre el comercio de especies amenazadas de fauna y flora silvestres CITES. Diario Oficial No. 93. Tomo No. 291, 23 Mayo

República de El Salvador R (1994) Convenio sobre la diversidad biológica. Diario Oficial No. 92. Tomo No. 323, 19 Mayo

República de El Salvador R (2001a) Ley de conservación de vida silvestre. Diario Oficial No. 133. Tomo No. 352, 16 Julio

República de El Salvador R (2001b) Ley general de ordenación y promoción de pesca y acuicultura. Diario Oficial No. 240. Tomo No. 353, 19 Diciembre

República de El Salvador R (2007) Reglamento de la ley general de ordenación y promoción de pesca y acuicultura. Diario Oficial No. 88. Tomo No. 375, 17 Mayo

República de El Salvador R (2009) Veda total y permanente al aprovechamiento de huevos, carne, grasa, aceite, sangre, huesos, especimenes disecados, caparazones, fragmentos y productos elaborados de caparazones de todas las especies de tortugas marinas. Diario Oficial No. 23. Tomo No. 382, 4 Febrero

Richardson JI, Bell R, Richardson TH (1999) Population ecology and demographic implications drawn from an 11-year study of nesting hawksbill turtles, Eretmochelys imbricata, at Jumby Bay, Long Island, Antigua, West Indies. Chelonian Conserv Biol 3:244-250

SEMA (Secretaria Ejecutiva del Medio Ambiente) (1994) Plan y estrategia del sistema salvadoreño de áreas protegidas. MAG, San Salvador

Seminoff JA, Nichols WJ, Resendiz A, Brooks L (2003) Occurrence of hawksbill turtles, Eretmochelys imbricata (Reptilia: Cheloniidae), near the Baja California Peninsula, Mexico. Pac Sci 57:9-16

Spotila JR (2004) Sea turtles: a complete guide to their biology, behavior, and conservation. Johns Hopkins University Press, Baltimore, MD

Vásquez M, Liles M, López W, Mariona G, Segovia J (2008) Sea turtle research and conservation, El Salvador. FUNZEL-ICMARES/UES, San Salvador

Wallace BP, DiMatteo AD, Hurley BJ, Finkbeiner EM and others (2010) Regional management units for marine turtles: a novel framework for prioritizing conservation and research across multiple scales. PLoS ONE 5:e15465

Wells S (2009) Dynamite fishing in northern Tanzania - pervasive, problematic and yet preventable. Mar Pollut Bull $58: 20-23$

Witzell WN (1983) Synopsis of biological data on the hawksbill turtle, Eretmochelys imbricata (Linnaeus, 1766). Fisheries Synopsis 137. Food and Agriculture Organization, Rome

Submitted: June 16, 2010; Accepted: January 24, 2011

Proofs received from author(s): March 27, 2011 